\title{
Cultural difference and consumer satisfaction when interacting with technology mediated customer services
}

\author{
Suhong Li, Bryant University, sli@bryant.edu \\ Kamel Rouibah, Kuwait University,ghallawy@gmail.com \\ Hal Records, Bryant University,hrecords@bryant.edu \\ Robert Behling, Arrowrock Industries, behlingr@hotmail.com
}

\begin{abstract}
Information technology mediated customer service is a reality of the $21^{\text {st }}$ century. This study seeks to answer the research question "Does culture influence consumer satisfaction when interacting with technology?" Using 668 responses collected from US, China and Kuwait, the study investigates customer preferences over two service delivery models along with perception differences in customer service quality. Some significant differences are found in both customer purchasing preferences and perception of customer service quality in the three different cultures. Even with these cultural differences, it appears there are greater similarities than differences across these widely different cultures, economies and geography, which suggests that the use of technology to support business operations continues to make our world smaller and ever more similar in positive and subtle ways.
\end{abstract}

Keywords: Customer service technology, customer service quality metrics, China, Kuwait, Arab

\section{Introduction}

Human resource costs are on the increase, while technology costs are on the decline. The U.S. Department of Labor (Labor, 2021) reported significant increases in compensation for the period between March 2020 and March 2021. Even with the pandemic and associated unemployment increases, compensation costs continue to rise. Moore's law states that "the number of transistors on a chip double every 18 months while the costs are halved, and this will continue into the foreseeable future" (Investopedia, 2018). This continual growth and refinement, as well as manufacturing cost reduction for the microprocessor, the core component for most modern technology, continues to make deploying technology to replace humans very financially attractive all over the world. More than twenty years ago many aspects of human interpersonal service encounters between customers and vendors started to be replaced with technology-based interfaces (Lee and Kailosh, 2007). We have found that service innovation, including technology mediated customer service, changes service concepts, client interaction channels, and service delivery systems (Van Ark et al, 2003 ) as well leading to the emergence of disruptive technology applications (e.g. Uber, airbnb, etc.). Over the past twenty or more years consumers have had the opportunity to interact with, and experience technology mediated service encounters.

Golkar (2018) reports that by the year 2020 it is predicted that 85 percent of all service requests will be managed without human interaction. One of the greatest challenges faced by organizations is how to

predict and manage the changes that occur both within the business and with customer relations that occur with technology adoption (Van Wageningen, 2017). It should be noted that some believe that introducing 


\section{Issues in Information Systems}

Volume 22, Issue 3, pp. 26-38, 2021

new technologies should not be done to replace people, technology should be utilized to enhance our abilities to more effectively service customer needs (Pratt, 2009).

\section{Technology and Business}

For most organizations, profits drive their business decisions, and cutting costs by utilizing technology in lieu of humans for collecting, managing and utilizing business information, including responding to service requests, can lead to improved profitability. Introducing new technologies, whether for business or personal use, transforms society, changes interactions, and impacts our cultural sense of the world (Pratt, 2009). An illustration of this can be seen with the research and development of this paper. Even though one author resides in Kuwait, the authors are able to share through the internet data, text, files, and anything else necessary to complete the paper, with transmission times measured in seconds or minutes. It is now possible to include individuals from diverse cultures into a work team or to collect and extract global data with a few simple keystrokes and a computer.

Replacing humans with technology to support customer service may save money, may lead to negative impact on society (e.g. increasing un-employment), but it may not save customer relationships. Customers often develop critical impressions of a firm during service encounters (Lee and Kailash, 2007), and when technology is used to support customer service activities and requests, some consumers have expressed dissatisfaction with the outcomes, and prefer to interact with human support staff (Records, et al, 2017). While in other cases the move toward full dependency on technology may lead to full shut down of service. This is the case of fire in the data center of the Ministry of Interior in Kuwait in April 2015. For three days the main information systems were shut down, including airport departure and arrival, and land exit borders, which caused high frustration and dissatisfaction among customers.

Automated systems cannot anticipate every eventuality; therefore there are occasions when customers seeking service become frustrated. Other consumers may prefer interacting with a computer rather than humans (Siau and Chen, 2016). We should not be surprised at this finding with all the technology that people utilize today: cell phones; tablets; electronic games; virtual reality devices; text messaging, e-mail; social media and much more. While technology utilization is not limited to any particular generation, young people have grown up surrounded by technology, and are generally more comfortable using it. Others may not embrace it with the same enthusiasm. Forester (2021) predicts important evolving service trends include: 1) AI empowering self-service technologies; 2) Speech analytics supporting agent guidance; and 3) Agent collaboration using AI.

\section{Technology and Culture}

The ease of deploying technology and communicating online continues to impact our cultures both locally and globally (Culture, 2013), and culture can influence the successful implementation and use of information technology (Leidner et al, 2006). Global cultures are divided by access and availability (Van Wageningen, 2017). Hernandez (2020) suggests that all sectors throughout the world: including agriculture, medicine, manufacturing and all forms of business are influenced and supported by technology. Both geography and economics come into play when describing global cultures and cultural norms tend to fall into general patterns. In individualistic cultures, people generally seek information on their own and to benefit only themselves; in collectivistic cultures, people rely on evaluation from like-minded individuals (Lee et al, 2013) and people who may influence their behavior. Individualistic cultures (e.g. USA) can be described as stressing the need of the individual over the need of the group, with people seen as independent and autonomous. Collectivistic cultures (e.g. Kuwait and China) stress the need to be generous, helpful, dependable, and attentive to the needs of others (Culture, 2018). People in collectivism cultures like to be together and to socialize during activities such as eating in a restaurant or shopping. Hofstede's culture 


\section{Issues in Information Systems}

Volume 22, Issue 3, pp. 26-38, 2021

dimensions (in term of uncertainty avoidance, power distance, masculinity/femininity, and individualism/collectivism) is the most used model across different disciplines (information system, marketing, and psychology). Several studies have included the Hofstede model in their technology adoption models. For example, McCoy, Galletta and King (2007) found that TAM applied across cultures, based on hosted culture dimensions, do not provide the same results and call for caution when applying technology adoption across culture. Yoon (2009) explored the effect of national culture on consumer acceptance of ecommerce in China and found that the Hofstede's dimension of culture affect consumer acceptance of ecommerce. Faqih and Jaradat (2015) found the moderation role of individualism collectivism at individuallevel values on the adoption of mobile commerce is significant in Jordan, which is an Arab country. According to Hostede (2001), members of cultures that are high in uncertainty avoidance (UA), e.g. Kuwait and China, are typically adverse to taking actions that have an uncertain outcome (e.g. using on-line transaction that involve on-line payment). In an Arab context, the role of UA had been highlighted as having a major effect on the adoption of high UA users towards technology adoption (El Said and Galal-Edeen 2009; Rouibah and Hamdy 2009).

Hernandez (2020), reports that while technology makes it easy to trade goods and services, share global news online, develop new products and explore investment opportunities, consumers worldwide face two significant challenges, a knowledge gap between generations and a digital divide, where the lack of financial resources limit access to emerging technologies. In any case, the deployment and use of technology directly influences culture, and one of our greatest challenges is how to manage cultural change that comes about with technology adoption (Van Wageningen, 2017). A study by Li, Records and Behling, (2018) surveyed individuals in the United States and China, and found both similarities and differences in perceptions and use of technology in mediated customer service, suggesting culture has some bearing on the acceptance of the replacement of humans with technology.

The Economist (2016) describes an excellent example of technology transforming culture. There are more mobile phones than adults in most African countries. The use of mobile phones is changing African cultures by providing expanded communication opportunities to distant communities and distant countries, with internet access bringing the modern world and economic opportunities to even the smallest villages, and cross border access without political or geographic concerns. IT was also a solution in Africa where the banking sector is lacking behind well developed countries. For example, M-Pesa is a mobile phone-based money transfer, financing and microfinancing service, launched in 2007 by Vodafone in Africa with low IT infrastructure that allows users to deposit, withdraw, transfer money and pay for goods and services easily with a mobile device without relying on banks IT infrastructure. Remote villages are now able to communicate with anyone, anywhere, for any reason. Africa is no longer the "dark continent" with inhabitants shielded from the power and economic engines of developed nations. While they may not always be able to effectively compete, technology has changed their culture enough to give them an opportunity to try.

\section{Customer Service and Technology}

New technologies can be used to help customer service professionals do their job more efficiently utilizing tools such as real-time messaging and Bots. Bots are branching perceptual logic presented through a conversational user interface, and are able to provide repeatable standard responses during a service inquiry. For example, the Emirate of Dubai uses a virtual assistant bot called "Rashid" in its Smart egovernment mobile application. It gives citizens, residents and tourists answers to their questions about living and working in Dubai on many topics, such as starting business, transportation, licensing, visas and residency, passports and certificates attestation, in addition to entertainment, parks, shopping and more. In some organizations customer service reps spend as much as $90 \%$ of their time repeating the same instructions and product explanations to a multitude of customers. Bots can do the repetitive job as well as humans at 


\section{Issues in Information Systems}

Volume 22, Issue 3, pp. 26-38, 2021

a much lower cost (Redboard, 2018). Positive customer service experiences are important to sustaining relationships. Satisfactory customer service for both business enterprises and customers now relies on technology to support service requests across geographic, economic and cultural boundaries. Kindzerski (2018), reports that first contact resolution is the goal for meeting service requests, and the use of Artificial Intelligence is revolutionizing organizations ability to effectively and efficiently meet customer service requests from anywhere and at any time (Golkar, 2018). Organizations that skillfully manage customer experiences during service encounters are rewarded with enhanced customer satisfaction, increased revenue, and greater satisfaction across functions and levels (Rawson et al, 2013). This research will focus on evaluating customer satisfaction with information technology mediated service. Survey responses from residents of the US, China and Kuwait are compared, looking for similarities and differences in the three surveyed groups.

\section{Methodology}

In order to evaluate customer service satisfaction with IT mediated service we first identified five types of retail purchasing commonly done by potential survey respondents. These are retail, eating out, banking, and travel and entertainment. Next we identified two dominant means or modes by which purchasing can be done; in-store and in-person, or through a computer or mobile device. For each type of purchasing, we developed seven items to measure how people perceive the relative value of each mode within each type of purchasing experience.

The survey was distributed to undergraduate students at a private northeastern U.S. university with 234 valid respondents. The survey was translated into Chinese and distributed through WeChat to undergraduate students at two large Chinese universities in Beijing with 208 valid respondents. The survey was also distributed in a public Kuwaiti university with 226 valid responses. The total sample size is 668 . For the US respondents, $61 \%$ (142) are male and 39\% (92) are female. For the Chinese students, $38 \%$ (78) are male and $62 \%(130)$ are female. For the Kuwaiti students, $29 \%(66)$ are male, and $71 \%(160)$ are female.

Table 1 shows the types of hardware devices owned by respondents and their inclination toward technology adoption. It can be seen nearly $100 \%$ have laptops and web-enabled smart phones for both the

US and Chinese students, this number reduced to $89 \%$ and $70 \%$ for Kuwaiti students. About half of the US and Chinese students have tablet computers and this number reduces to $40 \%$ for Kuwaiti students. It can be concluded that students in the US and China have more electronic devices than those in Kuwait. It should be noted that about $15 \%$ of Kuwaiti students have an apple watch, this number is reduced to $7 \%$ in the US and 3\% in China. In addition, about one third of American and Chinese students consider themselves as either eager beaver and early adopter of new technology/gadgets, while about half (45\%) of Kuwaiti students consider themselves as early adopters.

It can be concluded that there is a higher and similar adoption rate of hardware devices in the US and China compared to Kuwait. More than half of the respondents in all three countries own at least two devices. Given the age, hardware availability and pro-technology bias associated with this population it is anticipated that survey results are friendlier toward the use of IT mediated service than that of the purchasing population as a whole. 
Table 1. Devices and Attitude toward Technology Adoption

\begin{tabular}{|l|l|l|l|}
\hline Devices I Own & $\begin{array}{l}\text { US Respondents } \\
\text { Percent (Number) }\end{array}$ & $\begin{array}{l}\text { China } \\
\text { Respondents } \\
\text { Percent } \\
\text { (Number) }\end{array}$ & $\begin{array}{l}\text { Kuwaiti } \\
\text { Respondents } \\
\text { Percent (Number) }\end{array}$ \\
\hline Laptop/Computer & $100 \%(234)$ & $98.1 \% \%(204)$ & $70.4 \%(159)$ \\
\hline Smart Phone & $98.3 \%(230)$ & $98.1 \%(204)$ & $88.5 \%(200)$ \\
\hline Tablet (iPad, Samsung Note, etc.) & $47.9 \%(112)$ & $54.8 \%(114)$ & $39.8 \%(90)$ \\
\hline E-Reader (Kinder Fire, Nook, etc.) & $15.4 \%(26)$ & $23.6 \%(49)$ & $5.3 \%(12)$ \\
\hline Apple Watch & $6.8 \%(16)$ & $3.4 \%(7)$ & $15.4 \%(34)$ \\
\hline $\begin{array}{l}\text { I am always among the first to adopt new } \\
\text { technology and gadgets }\end{array}$ & & & \\
\hline Strongly Agree (Eagle Beaver) & $7.3 \%(17)$ & $9.1 \%(19)$ & $3.5 \%(8)$ \\
\hline Agree (Early Adopter) & $29.1 \%(68)$ & $26.9 \%(56)$ & $41.6 \%(94)$ \\
\hline $\begin{array}{l}\text { Neither Agree nor Disagree (Early } \\
\text { Majority) }\end{array}$ & $39.7 \%(93)$ & $51.4 \%(107)$ & $45.1(102)$ \\
\hline Disagree (Late Majority) & $20.9 \%(49)$ & $10.1 \%(21)$ & $7.1 \%(16)$ \\
\hline $\begin{array}{l}\text { Strongly Disagree (Technically } \\
\text { Adverse) }\end{array}$ & $3.0 \%(7)$ & $2.4 \%(5)$ & $2.7 \%(6)$ \\
\hline
\end{tabular}

\section{Data Analysis}

This section will use Chi-square to see whether there are significant differences in student purchasing preference (in-store or on-line) for each type of purchasing (Retail, Eating-Out, Banking, Travel and Entertainment) among the three countries. Paired samples t-tested will be then used to test whether there exist significant differences between in-store and on-line purchasing for each metric of customer service quality in the US, China, and Kuwait respectively.

\section{Purchasing Preference by Type of Purchasing}

A series of chi-square tests is conducted to see whether there exist any significant differences regarding student preference for each type of purchasing among three countries (see Table 2). The results show that significant differences are found for all types of purchasing except banking among three countries. Additional chi-square tests are conducted among every pair of three countries to see which two countries are significant.

For retailing, there is no significant difference between USA and Kuwait. There is a significant difference between China and the US, and between China and Kuwait. It can be seen from Table 2 that more students in the US and Kuwait prefer in-store and in-person for retail than those in China. For eating out, there is a significant difference among every pair of the three countries. 91\% of American students prefer in-store and in-person, followed by $84 \%$ of Chinese students and $57 \%$ of Kuwaiti students. For travelling, there is also a significant difference among every pair of the three countries; about $96 \%$ of Chinese students prefer on-line purchasing, followed by $82 \%$ of American students and $66 \%$ of Kuwait students. For entertainment, there is no significant difference between USA and Kuwait. There is significant difference between China and the US, and between China and Kuwait. Nearly 100\% of Chinese student prefer on-line purchasing compared to $67 \%$ for American students and $73 \%$ for Kuwaiti students.

It can be concluded that there is more similarity between the students in the US and Kuwait regarding their purchasing preference than those in China. More than half of the students in the US and Kuwait prefer in- 


\section{Issues in Information Systems}

Volume 22, Issue 3, pp. 26-38, 2021

store purchasing for retail, eating out and banking, and they prefer on-line purchasing for travel and entertainment. For Chinese students, the majority of the students (85\%) prefer in-store for eating out and more than half of them prefer on-line for the rest (retail, banking, travel and entertainment).

In addition, Chi-square tests are used to see whether there is any gender difference in student preferences for each type of purchasing in each country. The results show that retail purchasing is significant at both the US and China. There is no significant difference by gender in purchasing preferences for eating out, banking, travel and entertainment in both countries. In sum, female students in both countries prefer in-sore and in-person for retail purchasing. In Kuwait, there is significant difference by gender for banking. More male students prefer on-line banking than females.

It can be concluded gender difference for the younger generation among the three countries is disappearing. The new generation ( $\mathrm{Y}$ or $\mathrm{Z}$ ) are adopting the same regardless their culture or countries because they are all exposed to the same "water fall" trend in new technologies.

Table 2. Student Preferences by Type of Purchasing

\begin{tabular}{|c|c|c|c|c|c|c|c|}
\hline \multirow[b]{2}{*}{$\begin{array}{l}\text { Type of } \\
\text { Purchasing }\end{array}$} & \multicolumn{2}{|c|}{$\begin{array}{c}\text { Respondents } \\
\text { Preferences (USA) }\end{array}$} & \multicolumn{2}{|c|}{$\begin{array}{c}\text { Respondent } \\
\text { Preferences (China) }\end{array}$} & \multicolumn{2}{|c|}{$\begin{array}{c}\text { Respondent } \\
\text { Preferences (Kuwait) }\end{array}$} & \multirow[b]{2}{*}{$\begin{array}{c}\text { Chi-Square } \\
\text { Test }\end{array}$} \\
\hline & $\begin{array}{l}\text { In Store } \\
\text { and in } \\
\text { Person }\end{array}$ & $\begin{array}{l}\text { Through } \\
\text { Compute } \\
\text { r/Mobile } \\
\text { Device }\end{array}$ & $\begin{array}{l}\text { In } \\
\text { Store } \\
\text { and in } \\
\text { Person }\end{array}$ & $\begin{array}{l}\text { Through } \\
\text { Computer/ } \\
\text { Mobile } \\
\text { Device }\end{array}$ & $\begin{array}{l}\text { In Store } \\
\text { and in } \\
\text { Person }\end{array}$ & $\begin{array}{l}\text { Through } \\
\text { Computer/ } \\
\text { Mobile } \\
\text { Device }\end{array}$ & \\
\hline Retail & $\begin{array}{l}67.8 \% \\
(156)\end{array}$ & $\begin{array}{l}32.2 \% \\
(74)\end{array}$ & $\begin{array}{l}41.3 \% \\
(86)\end{array}$ & $58.7 \%(122)$ & $\begin{array}{l}65.9 \% \\
(149)\end{array}$ & $34.1 \%(77)$ & $\begin{array}{l}\text { chi-square }=38.65, \\
\mathrm{df}=2, \mathbf{p}=\mathbf{0 . 0 0}\end{array}$ \\
\hline $\begin{array}{l}\text { Eating } \\
\text { Out }\end{array}$ & $\begin{array}{l}90.8 \% \\
(198)\end{array}$ & $\begin{array}{l}9.2 \% \\
(20)\end{array}$ & $\begin{array}{l}84.6 \% \\
(176)\end{array}$ & $15.4 \%(32)$ & $\begin{array}{l}57.4 \% \\
(128)\end{array}$ & $42.6 \%(95)$ & $\begin{array}{l}\text { chi-square }=70.89, \\
\mathrm{df}=2, \mathbf{p}=\mathbf{0 . 0 0}\end{array}$ \\
\hline Banking & $\begin{array}{l}58.0 \% \\
(112)\end{array}$ & $\begin{array}{l}42.0 \% \\
(81)\end{array}$ & $\begin{array}{l}41.8 \% \\
(87)\end{array}$ & $58.2 \%(121)$ & $\begin{array}{l}50.2 \% \\
(112)\end{array}$ & $\begin{array}{l}49.8 \% \\
(111)\end{array}$ & $\begin{array}{l}\text { chi-square }=5.29 \\
\mathrm{df}=2, \mathrm{p}=0.07\end{array}$ \\
\hline Travel & $\begin{array}{l}17.7 \% \\
(39)\end{array}$ & $\begin{array}{l}82.3 \% \\
(181)\end{array}$ & $\begin{array}{l}3.8 \% \\
(8)\end{array}$ & $96.2 \%(200)$ & $\begin{array}{l}33.9 \% \\
(75)\end{array}$ & $\begin{array}{l}66.1 \% \\
(146)\end{array}$ & $\begin{array}{l}\text { chi-square }=61.05, \\
\mathrm{df}=2, \mathbf{p}=\mathbf{0 . 0 0}\end{array}$ \\
\hline $\begin{array}{l}\text { Entertai } \\
\text { nment }\end{array}$ & $\begin{array}{l}32.9 \% \\
(71)\end{array}$ & $\begin{array}{l}67.1 \% \\
(145)\end{array}$ & $\begin{array}{l}3.8 \% \\
(8)\end{array}$ & $96.2 \%(200)$ & $\begin{array}{l}27.1 \% \\
(60)\end{array}$ & $\begin{array}{l}72.9 \% \\
(161)\end{array}$ & $\begin{array}{l}\text { chi-square }=55.17, \\
\mathrm{df}=2, \mathbf{p}=\mathbf{0 . 0 0}\end{array}$ \\
\hline
\end{tabular}

\section{Customer Services Quality Comparison}

For each of the five purchasing categories we used paired sample t-tests to test whether there is a significant perception difference in customer service quality in each country between the two purchasing modes. The results show that there exists a significant difference between in-store and on-line purchasing for each category of purchasing in the three countries. Due to the page limit, the tables showing the results of paired sample t-tests were excluded from the paper and the results of the analysis will be discussed in the following section.

\section{Retail Purchasing}

The result of paired sample t-tests shows that for retail purchasing, there exist significant perception differences between in-store and on-line purchasing among the US students for each metric of customer service quality. Chart 1 shows that in-store purchasing received higher means for 3 (item 1, 4, and 7) out of 7 service quality measures. Those three measures (hospitality, security and customer service expectation) may be critical in determining students' preferences in in-store purchasing. Ordering through computer/mobile devices received higher means for the rest of the 4 items, which are all related to speed 


\section{Issues in Information Systems}

Volume 22, Issue 3, pp. 26-38, 2021

and efficiency of the ordering process. It can be concluded that the US students consider in-store ordering has better security and customer services, while ordering through computer/mobile devices has better speed and efficiency.

For Chinese and Kuwaiti students, for retail purchasing, there exist significant differences between in-store and on-line purchasing for each customer service quality metric except item 7 (customer service met your expectation). For Chinese students, on-line purchasing received higher means for all service quality measures except item 4 (you felt secure in doing your transactions). For Kuwaiti students, 2 (item 1 and 4) out of 6 measures received higher means for in-store purchasing. Again, it shows that hospitality and security is important in Kuwaiti respondents' preference in in-store purchasing.

In sum, the students in the three countries consider in-store purchasing is more secure than on-line ordering. The results also show that compared to American and Kuwaiti students, more Chinese students consider retail purchasing through computer/mobile devices have better customer services quality than in-store purchasing.

\section{Chart 1-Retail Purchasing}

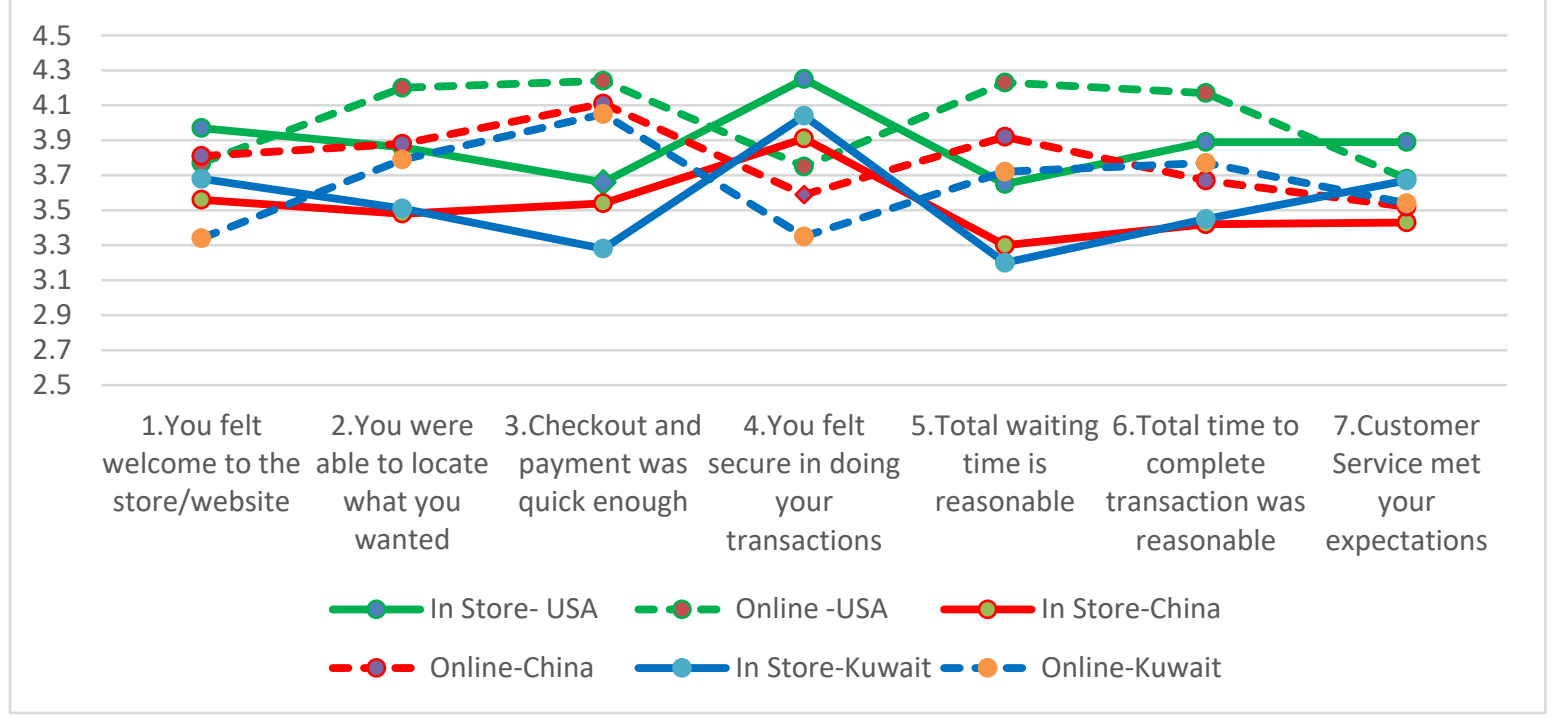

\section{Eating-Out}

For US students, there are significant differences between in-store and on-line for 4 out of 7 items (item $1,2,4$ and 7). Order in-store and in-person received higher means than ordering by computer/mobile service in all four items. This finding is consistent with the previous section showing US students prefer in-store and in-person when ordering eating out.

For Chinese students for eating out, there are significant differences between in-store and on-line for the 4 out of 7 items (item 1, 3, 4 and 7). Chart 2 shows that in store purchasing received significantly higher means for three items (item 1, 4 and 7). While ordering eating-out through computer/mobile devices received a higher mean for item 3. This finding is consistent with the previous section since Chinese students also chose in store and in person as their most preferred method of ordering eating out.

For Kuwaiti students, the findings show that 5 out of 7 items (item 1, 2, 3, 4 and 7) are significant. Chart 3 shows that order in-store and in-person received higher means for 4 items than ordering by computer/mobile 


\section{Issues in Information Systems}

Volume 22, Issue 3, pp. 26-38, 2021

devices. Similar to Chinese students, ordering eating out through computer/mobile devices received a higher mean for item checkout and payment was quick enough.

The students in all three countries consider in-store ordering as more welcoming, more secure, and meets their customer service expectations. Chinese and Kuwaiti students consider on-line ordering is more efficient/faster. Chart 2 shows American and Kuwaiti students give very similar rating for ordering eatingout through computer/mobile devices.

\section{Banking}

The result shows that that for American students, except item 5, all other service quality measures are significant. Chart 3 shows that in-store banking received higher means for 4 measures (item 1, 2, 3 and 6). On-line banking received higher means for one measurement (item 4). This is in consistent with previous result showing that more than half of the US students prefer in-store banking rather than on-line.

\section{Chart 2-Eating Out}

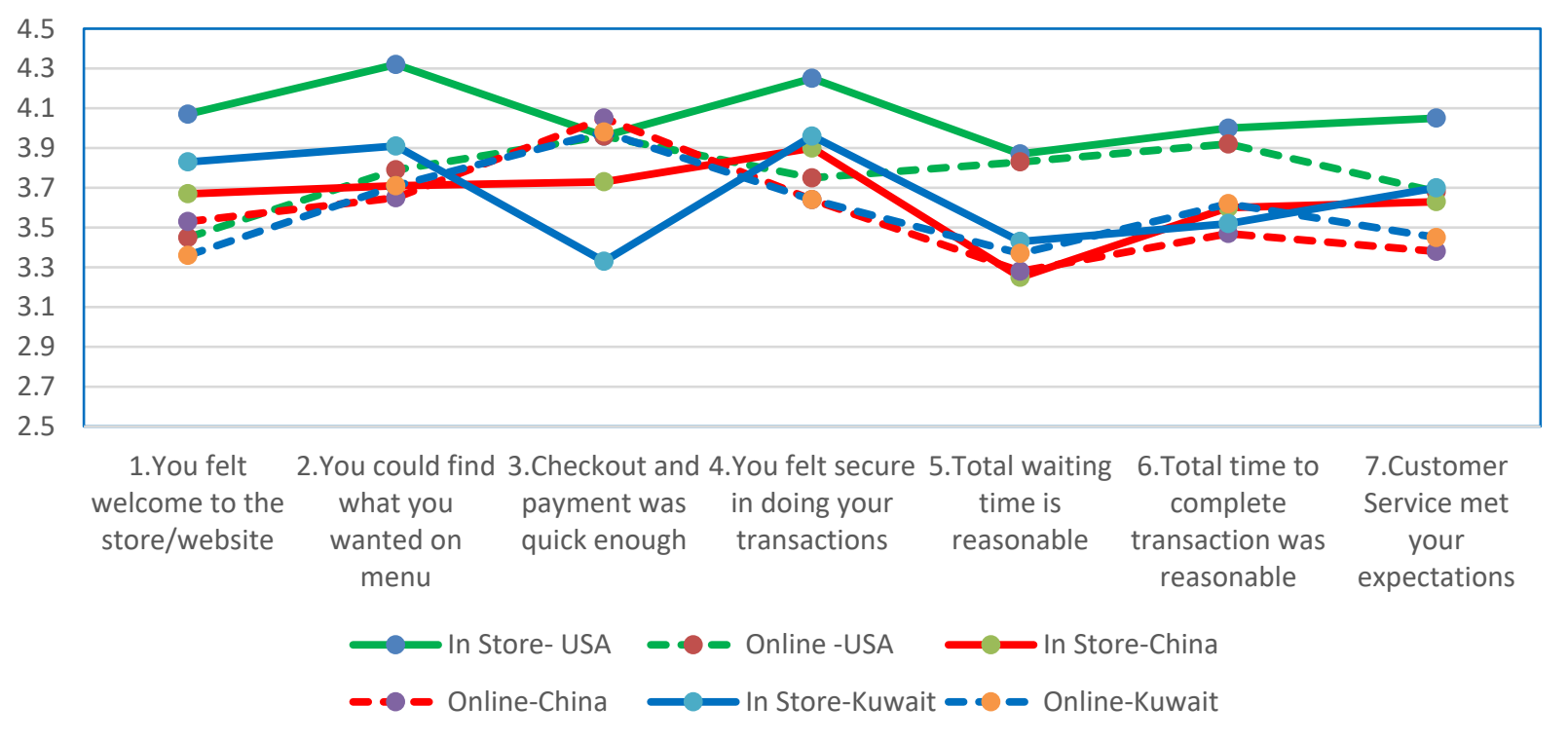

For Chinese students for banking, 3 service quality measures (item 3, 4, and 5) are significant. Among those three items, in-store banking received higher means for one item (item 3), and on-line banking received higher mean for two items (item 4 and 5). Previous results show that $58 \%$ of the Chinese students prefer on-line banking. It seems that transaction time is more important than security in choosing a preferred banking method for Chinese students.

For Kuwaiti students, 5 out of 6 service quality measures (except item 6) are significant. Similar to American students, in-store banking received higher means for three measures (item 1, 2, and 3). Similar to Chinese students, two items (item 4 and 5) received higher means in on-line banking than in-store banking. Again, in-store banking is considered more secure and on-line banking has less waiting time (more efficient) in all three countries. Chart 3 shows that total waiting time in bank in China received the lowest mean and the same item in Kuwait received the second lowest mean among all the items. 


\section{Issues in Information Systems}

Volume 22, Issue 3, pp. 26-38, 2021

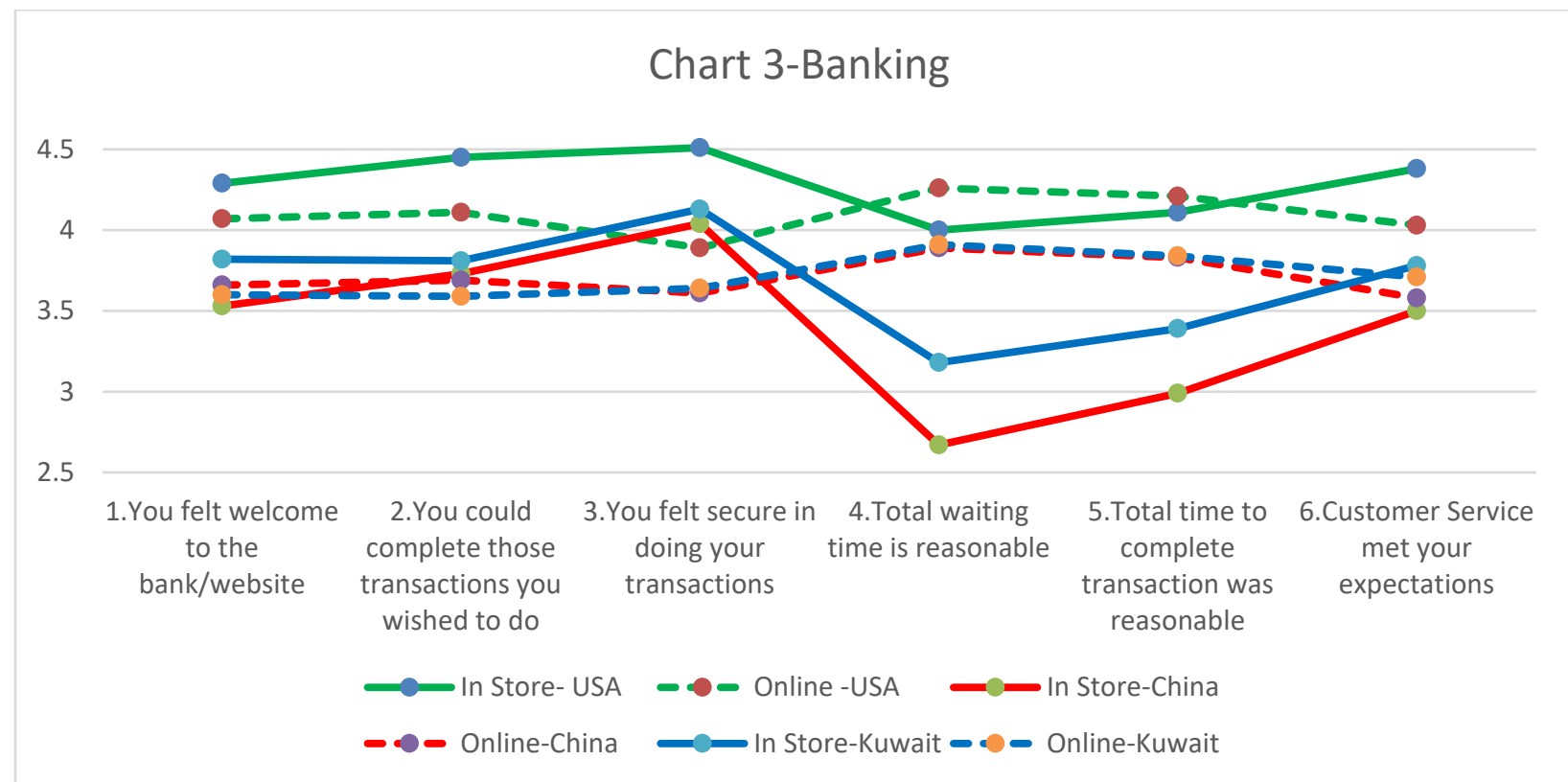

Travel

For travel there exists significant differences between in-store and on-line for most customer service quality measures for all the respondents. Purchasing through computer/mobile devices received higher means for all service quality measures except one item (item 4) in US and Kuwait. Those are consistent with our earlier findings, showing students chose computer/mobile device as their most preferred way of purchasing travelling tickets.

In addition, American and Kuwaiti students consider in-store purchasing more secure than on-line. However, for Chinese students, there is no significant difference regarding the security question between in store and online purchasing. This is surprising, in the earlier analysis for Chinese respondents ordering in-store is perceived more secure compared to ordering through computer/mobile device for retail, eatingout and banking.

Chart 4 shows that Chinese students have the lowest mean and Kuwaiti students have the second lowest mean for purchasing a travel ticket in-store for all service quality measures except security, indicating their dissatisfaction with in-store customer services.

\section{Entertainment}

The result shows that for American students, there are significant perception differences between in-store and on-line purchasing for 3 out of 7 measures (item 3,5 and 6). Chart 4 shows that American students consider online ticket purchasing having shorter waiting time and faster transaction compared to in-store purchasing. For Chinese students, there exists significant differences for all service quality measures between in store and on-line. On-line purchasing has a higher mean for all items. This is unexpected as online is usually viewed as less secure than in-store. For Kuwaiti students, except security measure (item 4), 6 measures are significant. Purchasing entertainment ticket through computer/mobile device received 


\section{Issues in Information Systems}

Volume 22, Issue 3, pp. 26-38, 2021

higher means for all 6 measures. Students in all three countries consider on-line purchasing for entertainment has better customer service quality than in-store, and they no longer consider in-store purchasing more secure than on-line. Chart 5 shows that Chinese students have the lowest means and Kuwaiti students have the second lowest means for purchasing entertainment ticket in-store for all service quality measures, indicating dissatisfaction with in-store customer services.

\section{Chart 4-Travel}
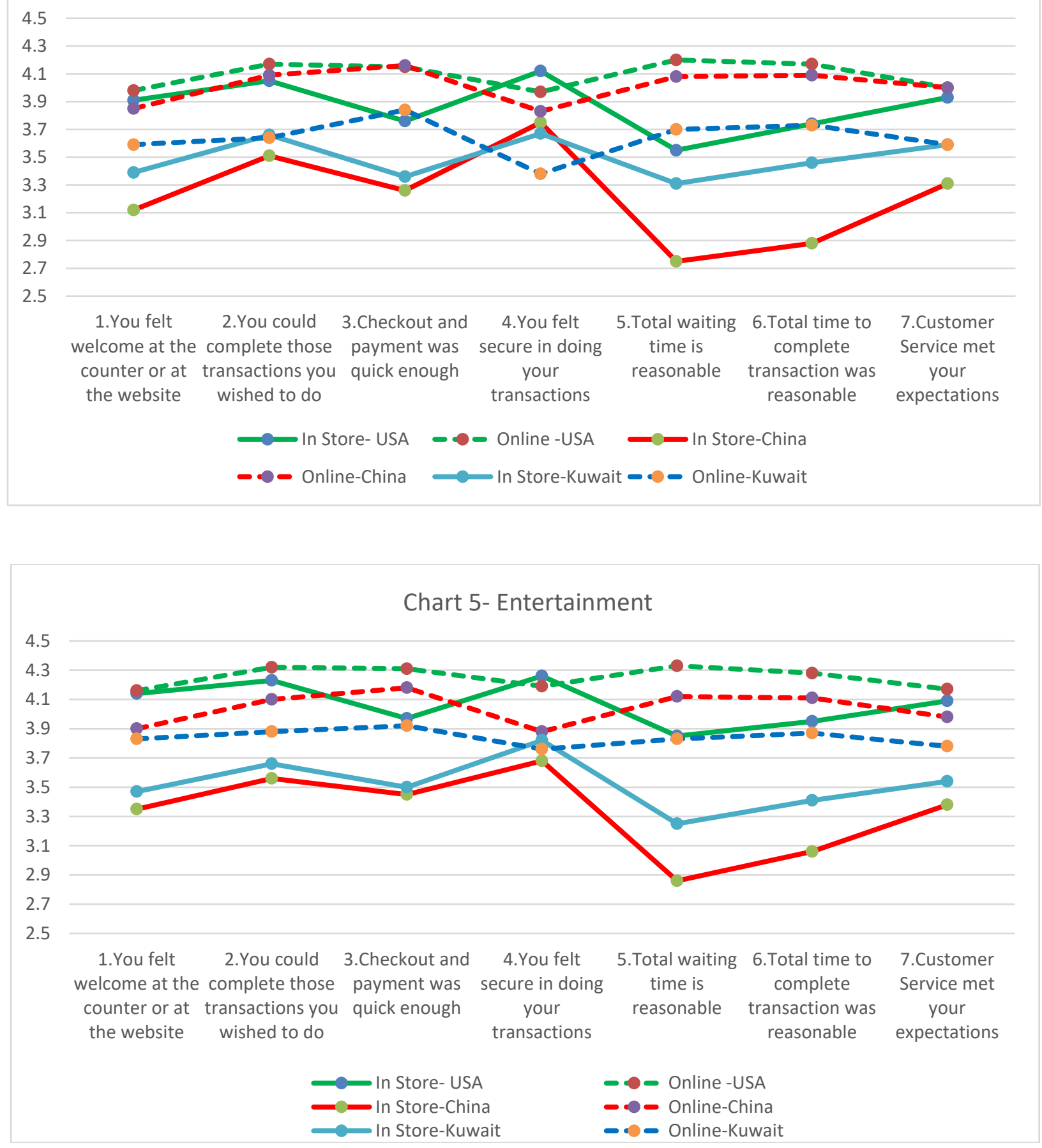


\section{Issues in Information Systems}

Volume 22, Issue 3, pp. 26-38, 2021

\section{Conclusion and Future Research}

This study investigates customer preferences over two service delivery models and five type of purchasing activities, and their perceived differences in customer service quality in the US, China and Kuwait. Significant differences among the countries are found in customer purchasing preferences for all types of purchasing except banking. More than half of the consumers in the US and Kuwait prefer in-store purchasing for retail, eating out and banking, and they prefer on-line purchasing for travel and entertainment. For Chinese students, the majority of the students prefer in-store for eating out and more than half of them prefer on-line for the rest. The results also show that there exists a significant perception difference in customer service quality over the two service delivery models in all three countries. For US and Kuwaiti respondents in-store purchasing received overall higher ratings in most of customer service quality measurement for retail, eating-out and banking, and lower means in most measures for travel and entertainment. Chinese students give higher ratings for ordering through computer/mobile devices in most of customer service quality measurements for all types of purchasing except eating out. On balance, it appears there are greater similarities than differences across widely different cultures, economies and geography, which suggests that technology continues to make our world smaller.

It is interesting to note that there are far more similarities than differences in perceptions of technology mediated customer services in all three countries. It is also interesting to note that by far the worst customer service experiences in all three countries are in-store total waiting time and total time to complete transactions. This is likely driving customers away from in-store shopping and toward on-line purchasing. It suggests that traditional stores need to review and streamline their checkout procedures and practices if they wish to stem the flow of business from brick and mortar to on-line stores. Is it any wonder that Amazon, Walmart on-line, Kohl's on-line, and other on-line retailers are gaining market share?

This study suffers from two limitations: first, results of the study cannot be generalized since the sample consisted of students who are highly computer literate and used a non-random sample. Second, while the focus was on service quality, we did not use the well-known SERVQUAL instruments, and instead used an internally generated instrument to collect data.

This study has several managerial and research implications. From a managerial perspective, results of this study point to several key service performance indicators that need attention by organizations. From a research perspective, this study lays the groundwork for continued study of factors that influence customer purchasing decisions.

\section{References}

(2016) "Mobile Phones are Transforming Africa," The Economist, Found at: www.economist.com/middle-east-and-africa/2016/12/10/mobile-phones-are-transforming-africa.

Culture. (2013) "Does Technology Impact Culture?" Found at: https://mediaculturesociety.org/2013/01/24/does-technology-impact-culture/.

Culture2. (2018) "Individualistic Cultures and Behavior," found at: www.verywellminded.com.

El Said, G. R., \& Galal-Edeen, G. H. (2009) "The Role of Culture in e-Commerce use for the Egyptian Consumer," Business Process Management Journal, 15(1), 34-47. 


\section{Issues in Information Systems}

Volume 22, Issue 3, pp. 26-38, 2021

Faqih K.M.S, and Jaradat M.R.M, (2015) "Assessing the Moderating Effect of Gender Differences and Individualism-Collectivism at Individual-Level on the Adoption of Mobile Commerce Technology: TAM3perspective," Journal of Retailing and Consumer Services, 22, 37-52.

Forester (2021) "The Three Customer Service Megatrends in 2021," found at http://callminer.com/thethree-customer-service-megatrends-in-2021.

Golkar, G. (2018) “Top 7 Customer Engagement Trends in 2018," Digital Customer Engagement, Found at: www.vocal/com.com/blog/digital-customer-engagement/Top-7-customer-engagement-trends-in$\underline{2018 .}$

Hernandez, T. (2020) "How Technology Affects Global \& Local Cultures," found at roxburyculturaldistrict.org/how-technology-affects-global-local-cultures/.

Hofstede, G. (2001) Culture's Consequences: Comparing Values, Behaviors, Institutions and Organizations across Nations, 2nd ed., Sage Publications, Thousand Oaks.

Investopedia. (2018) Found at: www.investopedia.com/terms/moores/law/asp.

Kindzerski, L. (2018) “The Top 10 Customer Experience Trends in 2018," Digital Customer Engagement. Found at: www.prnewswire.com/news-release/the-top-10-customer-experience-trends-in-2918.

Labor. (2021) "Employment Cost Index Summary," Bureau of Labor Statistics, U.S. Department of Labor, found at: www.blg.gov.news-release/eci,nr0.htm.

Lee, K. and J. Kailash (2007) "Customer Satisfaction with Technology Mediated Service Encounters," Journal of Information Technology Management, V. 18 , N. 2, pp18-37.

Lee, S., Trimi, S., and C. Kim (2013) "The Impact of Cultural Differences on Technology Adoption," Journal of World Business, V. 48, I. 1, pp 20-29.

Leidner, D. and T. Kayworth (2006) "Review: A Review of Culture in Information Systems Research: Toward a Theory of Information Culture Conflict," MIS Quarterly, V. 30, I.2, pp 357-399.

Li, S., Records, H., and R. Behling (2018) "A Comparison of Information Technology Mediated Customer Services Between the U.S. and China," Issues in Information Systems. V. 19, No. 1, pp. 1-10.

McCoy S., Galletta D.F., and King W.R., (2007) "Applying TAM Across Cultures: the Need for Caution", European Journal of Information Systems, 16, pp. 81-90.

Pratt, N. (2009) "Computers Changing our Values, Language and Culture," Found at: www.itbusiness.ca/news/computers-changing-our-values-language-culture/1459.

Rawson, A. E. Duncan and C. Jones. (2013) "The Truth About Customer Experiences," Harvard Business Review, September.

Records, H., Li, S., and R. Behling (2017) "Information Technology Service Quality and Customer Satisfaction," Issues in Information Systems, V. 18, No, 1, pp. 1-10. 


\section{Issues in Information Systems}

Volume 22, Issue 3, pp. 26-38, 2021

Rouibah, K., \& Hamdy, H. (2009) Factors Affecting Information Communication Technologies Usage and Satisfaction: Perspective from Instant Messaging in Kuwait. Journal of Global Information Management, 17(2), 1-29.

Redbord, M. (2018) "6 Predictions for the Future of Customer Service Technology," Found at: https://blog.hubspot.com/service/customer-service-technology.

Siau, K. and X Chen (2016) "Technology Mediated Synchronous Virtual Education: an Empirical Study," Journal of Database Management," V. 27,I 4, October, pp 39-63.

Van Wageningen, R. (2017) "The Role of Technological Change in Culture," Found at: www.orangebusiness.com/en/blogs/connecting-technology-/innovation/the-role-of-technological-change-inculture.

Yoon C. (2009) "The Effects of National Culture Values on Consumer Acceptance of e-commerce: Online Shoppers in China" Information \& Management 46 (2009) 294-301. 